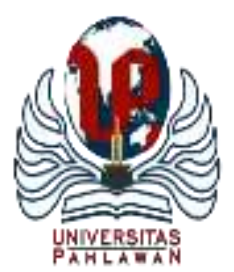

\title{
JURNALBASICEDU
}

Volume 6 Nomor 1 Tahun 2022 Halaman 491 - 498

Research \& Learningin Elementary Education

https://jbasic.org/index.php/basicedu

\section{Implementasi Literasi Baca Tulis dan Sains di Sekolah Dasar}

\author{
Maryono $^{1}$, Issaura Sherly Pamela ${ }^{2}$, Hendra Budiono ${ }^{3 凶}$
}

Pendidikan Guru Sekolah Dasar, Universitas Jambi, Indonesia ${ }^{1,2,3}$

E-mail: maryono@unja.ac.id ${ }^{1}, \underline{\text { issaurasherly@unja.ac.id }}^{2}, \underline{\text { hendra.budiono@unja.ac.id }}^{3}$

\begin{abstract}
Abstrak
Tujuan penelitian ini adalah untuk mendeskripsikan implementasi literasi baca tulis dan literasi sains di Sekolah Dasar 96/I Ladang Peris. Pendekatan penelitian yang digunakan adalah penelitian kualitatif dengan jenis penelitian fenomenologi. Data penelitian berupa deskripsi mengenai implementasi pelaksanaan gerakan literasi baca tulis dan literasi sains di kelas VI Sekolah Dasar 96/I Ladang Peris. Subjek penelitian adalah guru kelas VI Sekolah Dasar 96/I Ladang Peris. Instrumen penelitian yang digunakan adalah pedoman wawancara dan dokumentasi. Hasil penelitian menunjukkan pelaksanaan gerakan literasi baca tulis dan sains berada pada tahapan pengembangan. Upaya guru dalam mengembangkan literasi sains dan baca tulis adalah: 1) mendorong peserta didik menuliskan cerita dengan bahasanya sendiri, 2) jika pembelajaran tema yang memuat muatan sains selesai guru meminta peserta didik menuliskan rangkaian kegiatan pembelajaran (kegiatan pembelajaran dilaksanakan melalui percobaan) di dalam kertas satu lembar, 3) kegiatan berbagi cerita tentang buku yang dibaca, 4) bermain peran sesuai bacaan, 5) membuat pojok baca untuk peserta didik, 6) memperbaharui buku di pojok baca. Guru mengimplementasikan gerakan literasi baca tulis dan sains yang sangat bervariasi.
\end{abstract}

Kata Kunci: literasi, baca tulis, sains

\begin{abstract}
The purpose of this study was to describe the implementation of literacy and scientific literacy in 96/I Ladang Peris Elementary School. The research approach used is qualitative research with the type of phenomenological research. The research data is in the form of a description of the implementation of the literacy movement and scientific literacy in grade VI Elementary School 96/I Ladang Peris. The subject of the research was the sixth grade teacher of 96/I Ladang Peris Elementary School. The research instrument used was interview guide and documentation. The results of the study indicate that the implementation of the literacy and scientific literacy movement is at the development stage. The teacher's efforts in developing scientific literacy and literacy are: 1) encouraging students to write stories in their own language, 2) if the theme learning that contains science content is complete, the teacher asks students to write a series of learning activities (learning activities are carried out through experiments) on one sheet of paper, 3) activities to share stories about books read, 4) play roles according to reading, 5) create reading corners for students, 6) renew books in reading corners. Teachers implement various literacy and scientific literacy movements.
\end{abstract}

Keywords: literacy, reading and writing, science

Copyright (c) 2022 Maryono, Issaura Sherly Pamela, Hendra Budiono

$\triangle$ Corresponding author :

Email : hendra.budiono@unja.ac.id

DOI : https://doi.org/10.31004/basicedu.v6i1.1707

ISSN 2580-3735 (Media Cetak)

ISSN 2580-1147 (Media Online)

Jurnal Basicedu Vol 6 No 1 Tahun 2022

p-ISSN 2580-3735 e-ISSN 2580-1147 


\section{PENDAHULUAN}

Literasi menjadi kemampuan wajib peserta didik sekolah dasar yang harus dikembangkan. Peserta didik sekolah dasar dituntut untuk memiliki kemampuan literasi dasar; literasi bahasa, literasi numerasi, literasi sains, literasi digital, literasi finansial, dan literasi budaya kewargaan. Kemampuan literasi peserta didik sekolah dasar diupayakan pemerintah melalui gerakan literasi sekolah. Upaya tersebut dalam rangka mengimplementasikan Permendikbud Nomor 23 Tahun 2015 tentang Penumbuhan Budi Pekerti. Gerakan Literasi Sekolah (GLS) dalam menciptakan ekosistem pendidikan membiasakan peserta didik dengan budaya baca, tulis, dan hitung.

Literasi merupakan kemampuan individu dalam membaca dan menulis untuk mengelola informasi dan pengetahuan sebagai kecakapan hidup (KBBI). Literasi berkaitan dengan meningkatkan kemampuan individu dalam memahami informasi secara kritis, kreatif, dan reflektif melalui kegitan membaca, berpikir, dan menulis (Suyono et al., 2017). Istilah literasi secara umum berhubungan dengan kemampuan individu mengolah, menganalisi dan memahami informasi dalam kegiatan membaca atau menulis (Yunianika \& Suratinah, 2019). Literasi memberikan ruang berpikir bagi pembaca dengan hasil akhir memiliki kemampuan berpikir kritis dan pemecahan masalah. Diharapkan melalui gerakan literasi, kemampuan literasi dasar peserta didik dapat terkembangkan terutama literasi Bahasa dan sains untuk peserta didik sekolah dasar.

Kemampuan literasi baca tulis dan literasi sains yang baik pada jenjang sekolah dasar dapat membantu peserta didik dimasa akan datang. Literasi baca dan tulis adalah kecakapan dalam membaca, menulis, menelusuri, memanagemen, dan memahami informasi (Kementerian Pendidikan dan Kebudayaan, 2017). Literasi baca tulis penting untuk dikembangkan karena keterampilan membaca merupakan keterampilan utama untuk mencapai keterampilan lainnya. Keterampilan membaca merupakan keterampilan dasar wajib yang dimiliki setiap individu. Informasi di zaman era digital saat ini mudah diperoleh. Literasi baca tulis individu yang baik diharapkan mampu menganalisis dengan bijak informasi tersebut. Literasi baca tulis individu yang baik, tidak mudah terpengaruh dengan kondisi yang belum tentu kebenarannya.

Literasi sains merupakan kecakapan ilmiah dalam mengidentifikasi, memperoleh, menjelaskan, dan menyimpulkan informasi dan fenomena ilmiah berdasarkan fakta (Kementerian Pendidikan dan Kebudayaan, 2017). Literasi sains yang terbentuk di masyarakat merupakan salah satu fokus pembangunan masa globalisasi (Afni \& Rokhimawan, 2018). Masyarakat yang melek akan literasi sains mudah beradaptasi dengan kemajuan IPTEK yang terus berkembang (Nurfaidah, 2017). Selain itu literasi sains erat kaitannya dengan kemampuan berpikir ilmiah.

Kedua kemampuan dasar literasi tersebut dapat dikembangkan melalui Gerakan Literasi Sekolah (GLS). Guru sebagai fasilitator peserta didik wajib memiliki strategi dalam mengembangkan literasi baca tulis dan literasi sains peserta didik. Guru dapat melibatkan peserta didik dalam banyak kesempatan, kegiatan ini merupakan salah satu cara agar literasi dapat dikembangkan (Babinski et al., 2018). Kegiatan literasi mampu menjaga kesehatan otak, meningkatkan kecerdasan logika dan linguistik sehingga peserta didik yang intens membaca memiliki kecendrungan lebih baik memahami persoalan, baik hal yang berkaitan dengan pembelajaran di sekolah maupun kehidupan sehari-hari (Antoro, 2017).

Hasil observasi awal di kelas VI Sekolah Dasar 96/I Ladang Peris menunjukkan kegiatan literasi yang dilakukan guru sangat bervariatif. Salah satu kegiatannya adalah membaca buku yang berada di pojok baca dan menceritakan kembali isi cerita dengan bahasanya sendiri. Kegiatan tersebut dalam tahapan Gerakan Literasi Sekolah (GLS) merupakan tahapan pengembangan. Hasil observasi awal ini menarik untuk diteliti. Kegiatan Gerakan Literasi Sekolah (GLS) seperti apa yang dilakukan oleh guru tersebut. Bagaiamana strategi guru yang lainnya untuk meningkatkan kemampuan literasi peserta didiknya. Berdasarkan uraian tersebut maka tujuan penelitian ini adalah mendeskripsikan implementasi literasi baca tulis dan literasi sains di Sekolah Dasar 96/I Ladang Peris. 

Hendra Budiono

DOI: https://doi.org/10.31004/basicedu.v6i1.1707

\section{METODE PENELITIAN}

Pendekatan penelitian yang digunakan adalah pendekatan kualitatif. Pendekatan kualitatif pada penelitian ini bertujuan untuk mendeskripsikan atau mengambarkan fenomena implementasi literasi baca tulis dan literasi sains. Jenis penelitian yang digunakan adalah fenomenologi. Fenomenologi dilakukan untuk melihat pengalam guru dalam menghadapi fenomena Gerakan Literasi Sekolah (GLS) dalam mengembangkan literasi baca tulis dan literasi sains peserta didik.

Data penelitian ini adalah berupa deskripsi mengenai implementasi pelaksanaan gerakan literasi baca tulis dan literasi sains di kelas VI Sekolah Dasar 96/I Ladang Peris. Subjek penelitian adalah guru kelas VI Sekolah Dasar 96/I Ladang Peris. Pengambilan subjek penelitian melihat kriteria yaitu guru kelas tinggi yang mengimplementasikan literasi baca tulis dan sains di kelasnya.

Teknik pengumpulan data diperoleh melalui wawancara dan dokumentasi. Teknik wawancara yang dilakukan adalah wawancara mendalam. Wawancara dilakukan dengan mengajukan pertanyaan mengenai pengalaman guru dalam mengimplemtasikan literasi baca tulis dan sains. Wawancara dilaksanakan sampai memperoleh data jenuh. Instrumen penelitian adalah pedoman wawancara dan dokumentasi. Berikut tabel pedoman wawancara yang digunakan dalam penelitian:

Tabel 1. Pedoman Wawancara Penelitian

\begin{tabular}{lll}
\hline \multicolumn{1}{c}{ Subjek } & \multicolumn{3}{c}{ Petanyaan } \\
\hline & Bagaimana pelaksanaan gerakan literasi \\
& $\begin{array}{l}\text { sekolah khusus literasi baca tulis dan } \\
\text { literasi sains }\end{array}$ \\
\cline { 2 - 5 } 2. $\begin{array}{l}\text { Bagaiaman pengalaman Ibu dalam } \\
\text { mengimplementasikan literasi baca tulis } \\
\text { dan literasi sains }\end{array}$ & $\begin{array}{l}\text { Apa kegiatan literasi yang sering } \\
\text { dilaksanakan? }\end{array}$ \\
\hline 4. & $\begin{array}{l}\text { Bagaimana hasil dari implementasi } \\
\text { literasi baca tulis dan saisn tersebut? }\end{array}$ \\
\hline
\end{tabular}

Keabsahan data dilakukan untuk mengecek validitas data. Mengecek keabsahan data melalui kegiatan tirangulasi waktu dan sumber. Triangulasi waktu ketika wawancara dilakukan dengan waktu yang berbeda namun pertanyaan sama. Triangulasi sumber adalah wawancara dengan informan yang berbeda, dalam penelitian ini adalah guru teman sejawat, peserta didik, dan kepala sekolah. Data dianalis dengan model Miles dan Huberman dengan 4 tahapan: mengumpulkan data, mereduksi data, memyimpulkan data, dan membuat laporan.

\section{HASIL DAN PEMBAHASAN}

Hasil penelitian diperoleh melalui wawancara mendalam dengan guru kelas VI Sekolah Dasar Ngeri 96/I Ladang Peris sebagai informan utama dalam penelitian. Hasil wawancara menyatakan pengalaman guru dalam mengimplementasikan literasi baca tulis dan literasi sains tergolong tahap pengembangan pada Gerakan Literasi Sekolah (GLS). Hasil wawancara dengan guru kelas dicek keabsahan datanya dengan kepala sekolah dan guru teman sejawat. Hasil wawancara dengan kepala sekolah dan guru teman sejawat sama. Berdasarkan wawancara hasil penelitian, pengalaman guru dalam dalam mengembangkan literasi baca tulis dan literasi sains peserta didiknya sebagai berikut:

1. Mendorong peserta didik menuliskan kembali buku bacaan dengan bahasa sendiri setelah membaca 15 menit. Dimana buku bacaan yang dibaca bukan buku pelajaran baik berupa buku tema ataupun yang 
Implementasi Literasi Baca Tulis dan Sains di Sekolah Dasar - Maryono, Issaura Sherly Pamela, Hendra Budiono

DOI: https://doi.org/10.31004/basicedu.v6i1.1707

lainnya. Buku bacaan ini adalah buku bebas, seperti fiksi, dongeng, dll. Kegiatan menulis bacaan dilaksanakan untuk mengembangkan literasi baca tulis peserta didik .

2. Menuliskan kembali rangkaian kegiatan pembelajaran praktek sains dalam kertas selembar. Hal ini dilaksanakan untuk menggembangkan sikap ilmiah peserta didik dalam pembelajaran. Kegiatan berbagi cerita dilaksanakan untuk mengembangkan literasi baca tulis peserta didik.

3. Memceritakan kembali secara lisan buku bacaan ke depan kelas. Buku bacaan adalah buku bebas, seperti fiksi, dongeng, dll. Kegiatan berbagi cerita dilaksanakan untuk mengembangkan literasi baca tulis peserta didik. Sebelum meceritakan kembali isi buku bacaan, guru menanyakan ke peserta didik mengenai bagaimana gambar di buku tersebut, apa gambarnya, apa judulnya. Pertanyaan ini diajukan guru untuk membantu opeserta didik dalam menceritakan kembali isi bacaan.

4. Bermain peran sesuai buku bacaan. Kegiatan ini dilaksanakan untuk mengembangkan keterampilan membaca peserta didik ekspresi atau situasi bacaan.

5. Membuat pojok baca yang nyaman untuk peserta didik. Pojok baca berisi buku-buku pelajaran dan nonpelajaran. Buku yang tersedia berasal dari peserta didik.

6. Memperharui buku bacaan di pojok baca. Buku bacaan diperbaharui setiap per 3 bulan.

Hasil wawancara dapat dilihat pada tabel 2 cuplikan wawancara dengan guru. Cuplikan wawancara ini merupakan data jenuh, dimana peneliti telah mewawancarai guru dengan pertanyaan berulang diwaktu yang berbeda.

Terkait dengan pelaksanaan gerakan literasi sekolah khusus literasi baca tulis dan literasi sains dijelaskan bahwa kegiatan literasi di kelas cukup beragam. Pelaksanaannya melibatkan banyak dukungan sekitar, misalnya warga sekolah. Khusus literasi baca tulis saya meminta peserta didik untuk menuliskan kembali cerita ke buku catatannya dan memceritakan kembali cerita yang telah di baca ke depan kelas. Kegiatan ini mirip dengan model SQ3R. Namun khusus literasi sains saya meminta peserta didik menuliskan percobaan yang telah dilakukan dari awal sampai akhir memperoleh hasil percobaan. Kegiatan literasi yang dilakukan oleh guru dalam penelitian ini sesuai dengan hasil penelitian Chinditya et al., (2020) yang menyatakan bhawa salah satu bentuk literasi baca tulisa salah satunya adalah kegiatan memebaca berbasis cerita rakyat yang dapat dilakukan gur dalam proses pembelajaran.

Hasil wawancara juga menunjukkan bahwa penerapan literasi tergolong unik, banyak cerita dan kesan dalam meningkatkan literasi peserta didik. Misalnya dalam pembuatan pojok baca dan pembaharuan buku. Terkadang tidak mudah memperoleh buku. Dikarenakan desa jauh dari pusat pembelanjaan, sehingga peserta didik sulit mencari buku. Tidak jarang selaku guru meminta peserta didik saling menukar buku bacaan agar bacaan mereka bervariasi. Terkadang 3-4 bulan sekali memperbaharui buku di pojok baca. Pembuatan pojok baca senyaman mungkin untuk peserta didik agar mereka termotivasi dalam membaca. Kharizmi (2015) mengungkapkan bahwa berhubungan dengan sekolah dasar, sistem persekolahan masih kurang memberi peluang bagi tradisi literasi kepada peserta didik. Model pengajaran di kelas disampaikan dengan pendekatan teacher center yang memposisikan siswa sebagai pendengar. Kegiatan membaca sebagai kerangka berpijak dalam pembelajarannya masih sangat jarang diterapkan oleh guru. Oleh karena itu, para siswa tidak menemukan atau tidak terfasilitasi terhadap perkembangan literasi mereka sehingga budaya literasi yang mendambakan generasi literat akan sangat sulit dicapai.

Terkait dengan kegiatan literasi apa saja yang sering dilakukan, didapat data bahwa Kegiatan literasi sebelum pandemic banyak sekali yang terlaksana dengan baik, namun selama pandemic tidak banyak kegiatan literasi yang dapat kami laksanakan seperti membaca bersama, membaca dalam hati, menuliskan hasil cerita dengan kalimat sendiri, menceritakan isi buku ke depan kelasm menuliskan kegiatan percobaan dengan bahas sendiri serta bermain peran sesuai cerita. Cahyono \& Ardhyantama (2020) mengungkapkan bahwa literasi baca tulis adalah satu dari enam literasi dasar yang penting untuk dikuasai. Literasi baca tulis merupakan dasar 
literasi yang harus dikuasai untuk mendukung kelancaran literasi lainnya. Hasil literasi baca tulis menunjukkan bahwa Setiap kegiatan yang dilaksanakan secara rutin, berdampak positif untuk peserta didik. Ada perkembangan kemampuan literasi peserta didik. Literasi peserta didik meningkat dengan kegiatan yang telah dilaksanakan. Hal ini kurang berlaku di zaman pandemik ini. Semakin banyak peserta didik membaca maka semakin baik literasinya. Nurcholis \& Istiningsih (2021) menyatakan bahwa Pembelajaran Daring, dapat dilaksanakan apabila antara siswa dan guru mampu mengikuti perkembangan tekhnologi saat ini, dimana semua pembelajaran dilakukan dengan sebuah gadget atau benda lain yang mampu mendukung pembelajaran secara daring salah satunya adalah literasi baca-tulis.

Hasil wawancara diperkuat dengan pendokumentasian pojok baca yang terdapat di kelas VI Sekolah Dasar 96/I Ladang Peris. Berikut gambar yang peneliti ambil selama berada di sekolah.

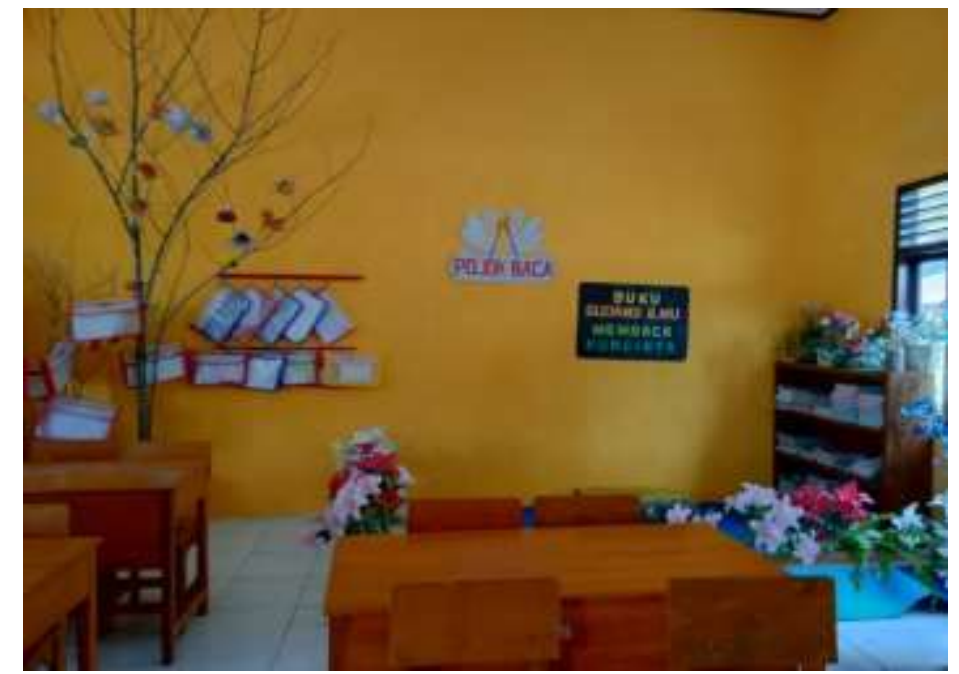

Gambar 1. Pojok Baca Kelas VI Ranting Pohon yang Telah Mati



Gambar 2. Pojok Baca Kelas VI Berwarna Cerah

Alat dan bahan hiasan pojok baca banyak berasal dari barang bekas. Barang bekas yang digunakan seperti botol plastik, sedotan, kresek berwarna, dan ranting pohon. Pojok baca yang didesain dengan warnawarna cerah sehingga peserta didik tertarik membaca buku di pojok baca. Dasarnya peserta didik sekolah 
dasar sangat meyukai warna-warna cerah. Kata motivasi "Buku Gudang Ilmu Membaca Kuncinya" terdapat di dinding pojok baca mendorong minat peserta didik untuk gemar membaca.

Hasil analisis dokumen Rencana Pelaksanaan Pembelajaran (RPP) yang dirancang menunjukkan literasi diimplementasikan sebelum kegiatan pembelajaran dimulai. Setelah kegiatan menyanyikan lagu Indonesia Raya peserta didik diminta untuk ke pojok baca mencari buku yang menarik untuk dibaca. Kegiatan membaca pada RPP berdurasi 10-15 menit. Hasil analisis dokumen memperkuat hasil wawancara dengan guru.

Pengalaman guru dalam mengimplemtasikan literasi baca tulis dan literasi sains sangat bervariatif. Kegitan yang dilaksanakan mampu mengembangkan keterampilan literasi baca tulis dan literasi sains peserta didik. Guru kelas sangat kreatif dan inovatif dalam membantu peserta didik mencapai keterampilan literasi baca tulis dan sains. Inovasi seperti ini dapat dijadikan contoh untuk guru jenjang sekolah dasar. Hal ini sesuai dengan pendaat Karli (2018) yang menjelaskan bahwa kegiatan di sekolah tidak lain kegiatan belajar mengajar di kelas. Gurulah yang menjadi fasilitator dan mentor untuk menggali dan membiasakan anak berpikir kreatif dan kritis. Literasi sains sebagai jembatan yang menghubungkan antara pendidikan dan dunia nyata siswa. Selanjutnya Nuro et al., (2020) menjelaskan bahwa usia di SD peserta didik mempunyai rasa skeptis/ rasa ingin tahun tinggi maka perlu diwadahi dengan literasi sains, sehingga dapat melakukan ujicoba sederhana. Selanjutnya Yuliati (2016) mengungkapkan bahwa pada tingkat sekolah dasar Ilmu Pengetahuan Alam atau sains merupakan salah satu mata pelajaran yang menduduki peranan penting dalam pendidikan hal ini dikarenakan sains dapat menjadi bekal bagi peserta didik dalam menghadapi berbagai tantangan di era global.

Kegiatan menuliskan dan menceritakan kembali isi cerita merupakan cara yang dilakukan guru dalam mengembangkan keterampilan literasi baca tulis. Kegiatan ini terbukti mampu mengembangkan literasi baca tulis peserta didik. Hal ini sejalan dengan pendapat (Yunianika \& Suratinah, 2019) menceritakan kembali isi cerita merupakan program yang dapat dilakukan untuk mengembangkan literasi peserta didik. Keterampilan Menuliskan dan menceritakan dengan bahasa sendiri mendorong peserta didik berpikir dalam menyusun kata menjadi kalimat yang tepat, menyampaikan informasi pada bacaan, memanagemen diri dalam memahami isi bacaan, dan mampu memberikan inspirasi peserta didik dalam menulis cerita pendek pada kompetensi pembelajaran Bahasa Indonesia. Keterampilan menulis merupakan salah satu keterampilan berbahasa yang wajib dimiliki peserta didik. Keterampilan menulis peserta didik memiliki peranan penting dalam kehidupan sehari-hari (Agustina, 2020). Keterampilan menulis di sekolah dasar merupakan pondasi untuk menulis di sekolah lanjutan. Jika pondasinya sudah kuat di sekolah dasar maka untuk pengembangan keterampilan menulis dilanjutan tidak begitu masalah (Mu'awwanah, 2017). Keterampilan bercerita sejalan dengan keterampilan berbicara. Peserta didik yang terampil berbicara akan memiliki nalar yang tinggi dan menyusun kata menjadi kalimat yang runut (Nurlaila, 2019).

Menuliskan kegiatan percobaan dengan bahasa sendiri merupakan tujuan untuk meningkatkan keterampilan berpikir ilmiah peserta didik. Program ini dapat meningkatkan literasi sains peserta didik dengan baik. Kegiatan ini sama dengan membuat laporan ilmiah dari percobaan. Laporan ilmiah adalah laporan untuk meyampaikan hasil dari percobaan yagn dilakukan untuk meneliti sesuatu (Keraf, 2001). Pelaporan hasil percobaan membantu peserta didik dalam mengkonstuk pemikirannya dalam pembelajaran sains. Sebelum menuliskan laporan keterlibatan peserta didik aktif akan membantu proses penulis laporan ilmiah. Penulisan laporan ilmiah juga dapat dijadikan alat penilaian keterlibatan peserta didik dalam pembelajaran.

Pojok baca merupakan tempat (biasanya dipojok kelas) dimana peserta didik dapat membaca buku baik dalam waktu pelajaran ataupun diwaktu istirahat. Keberadaan pojok baca di setiap kelas bertujuan untuk memfasilitasi dan meningkatkan minat baca peserta didik. Program pengadaan pojok baca booming saat Gerakan Literasi Sekolah (GLS) diimplementasikan sekolah. Pojok baca di kelas VI sangat indah dan tertata rapi. Hiasan pojok baca yang berwarna-warni menambah indahnya pojok baca. Kebersihan di pojok baca juga diperhatikan, terlihat pojok baca kelas sangat bersih. Pojok baca dapat dikatakan perpustakaan mini yang 
berda di dalam kelas. Fungsi pojok baca membiasakan peserta didik untuk rajin membaca buku baik buku pelajaran maupun non-pelajaran (Hidayatulloh et al., 2019). Menyediakan fasilitas ruang baca di pojok kelas dengan desain yang menarik bagi peserta didik dan disesuaikan dengan kebutuhan peserta didik merupakan bentuk nyata dari pojok baca (Aswat \& Nurmaya, 2019).

Buku di pojok baca wajib untuk diperbaharui agar peserta didik tidak bosan dengan buku yang sama sepanjang waktu. Apa yang telah dilakukan oleh guru kelas VI sangat baik, beliau berusaha untuk memperbaharui buku di pojok baca minimal 3 bulan sekali. Memperbaharui buku di pojok baca merupakan strategi dalam mengatasi permasalahan koleksi buku yang kurang diminati oleh peserta didik (Irma et al., 2021).

\section{KESIMPULAN}

Simpulan penelitian adalah guru sebagai fasilitator peserta didik wajib untuk berinovasi dalam mengembangkan kemampuan literasi peserta didik. Literasi baca tulis dan literasi sains merupakan literasi dasar yang harus dikembangkan. Hal ini seusai dengan Penumbuhan Budi Pekerti dengan Gerakan Literasi Sekolah (GLS). Kegiatan yang dapat dilakukan dalam mengembangkan literasi baca tulis dan sains adalah 1) membaca buku cerita dan menuliskan kembali dengan bahasa peserta didik sendiri, 2) menceritakan kembali buku bacaan di depan kelas, 3) menuliskan dengan bahasa sendiri kegiatan percobaan/praktikum dari awal sampai hasil percobaan, 4) bermain peran sesuai bacaan, 5) membuat pojok baca, 6) mempebaharui buku bacaan.

\section{UCAPAN TERIMA KASIH}

Terima kasih diucapkan kepada Universitas Jambi melalui lembaga Penelitian dan pengabdian Masyarakat (LPPM) yang telah memberikan bantuan dana dalam penelitian ini. Selanjutnya ucapan terimakasih kepada tim peneliti dan pihak terkait yang telah berkontribusi terhadap penelitian ini.

\section{DAFTAR PUSTAKA}

Afni, N., \& Rokhimawan, M. A. (2018). Literasi Sains Peserta Didik Kelas V Di Min Tanuraksan Kebumen. Al-Bidayah: Jurnal Pendidikan Dasar Islam, 10(1), 47-68. Https://Doi.Org/10.14421/AlBidayah.V10i1.129

Antoro. (2017). Gerakan Literasi Sekolah Dari Pucuk Hingga Akar Sebuah Refleksi. Jakarta: Direktorat Jendral Pendidikan Dasar Dan Menengah Kementrian Pendidikan Dan Kebudayaan.

Aswat, H., \& Nurmaya G, A. L. (2019). Analisis Gerakan Literasi Pojok Baca Kelas Terhadap Eksistensi Dayabaca Anak Di Sekolah Dasar. Jurnal Basicedu, 4(1), 70-78. Https://Doi.Org/10.31004/Basicedu.V4i1.302

Babinski, L. M., Amendum, S. J., Knotek, S. E., Sánchez, M., \& Malone, P. (2018). Improving Young English Learners' Language And Literacy Skills Through Teacher Professional Development: A Randomized Controlled Trial. American Educational Research Journal, 55(1), 117-143. Https://Doi.Org/10.3102/0002831217732335

Cahyono, A. H., \& Ardhyantama, V. (2020). Pengembangan Literasi Baca Tulis Di Sekolah Dasar Islam Terpadu Ar Rahmah Pacitan. Alpen: Jurnal Pendidikan Dasar, 4(1), 8-16. Https://Doi.Org/10.24929/Alpen.V4i1.36

Chinditya, C. C., Susanta, A. S., \& Muktadir, A. M. (2020). Implementasi Literasi Dalam Pembelajaran Membaca Berbasis Cerita Rakyat Bengkulu Pada Siswa Kelas Iv Sd It Al-Qiswah Bengkulu. Jurnal 
Implementasi Literasi Baca Tulis dan Sains di Sekolah Dasar - Maryono, Issaura Sherly Pamela, Hendra Budiono

DOI: https://doi.org/10.31004/basicedu.v6i1.1707

Pembelajaran Dan Pengajaran Pendidikan Dasar, 3(2), 184-196.

Https://Doi.Org/10.33369/Dikdas.V3i2.14131

Hamelia Agustina. (2020). Penerapan Model Pembelajaran Kooperatif Tipe Roundtable Berbantuan Media Gambar Seri Dalam Meningkatkan Kemampuan Menulis Cerita Pendek Pada Siswa Sekolah Dasar Hamelia Agustina. Jurnal Gentala Pendidikan Dasar, 5(I), 78-90. Https://OnlineJournal.Unja.Ac.Id/Gentala/Article/View/9424

Hidayatulloh, P., Solihatul, A., Setyo, E., Fanantya, R. H., Arum, S. M., Istiqomah, R. T. U. N., \& Purwanti, S. N. (2019). Peningkatan Budaya Literasi Melalui Kegiatan Pojok Baca Di Sd Muhammadiyah Plus Malangjiwan Colomadu. Buletin Literasi Budaya Sekolah, 1(1), 6-11. Https://Doi.Org/10.23917/Blbs.V1i1.9301

Irma, I., Azis, S. A., \& Sulfasyah, S. (2021). The Profile Of School Literacy Movement As An Effort To Increase Reading Motivation For Primary School Students In Kabupaten Bone. Primary: Jurnal Pendidikan Guru Sekolah Dasar, 10(3), 656. Https://Doi.Org/10.33578/Jpfkip.V10i3.8200

Karli, H. (2018). Implementasi Literasi Sains Dalam Pembelajaran Di Sekolah Dasar. Jurnal Pendidikan Penabur, 30(Query Date: 2020-08-14 14:24:03), 1-19.

Kementerian Pendidikan Dan Kebudayaan. (2017). Materi Pendukung Literasi Sains. Gerakan Literasi Nasional, 1-36.

Keraf, G. (2001). Argumentasi Dan Narasi. Pt Gramedia Pustaka Utama.

Kharizmi, M. (2015). Feldpostbrief Des Staatlichen Gymnasiums Dresden-Neustadt. Jupendas: Jurnal Pendidikan Dasar, 2(2), 11-21. Https://Www.Neliti.Com/Id/Publications/71420/Kesulitan-SiswaSekolah-Dasar-Dalam-Meningkatkan-Kemampuan-Literasi

Mu'awwanah. (2017). Kemampuan Menulis Cerita Di Sd. Jurnal Guru Kita (Jgk)., 1(2), 26-39.

Nurcholis, R. A., \& Istiningsih, G. (2021). Problematika Dan Solusi Program Literasi Baca-Tulis. Jurnal Ilmiah Profesi Pendidikan.

Nurfaidah, S. S. (2017). Analisis Aspek Literasi Sains Pada Buku Teks Pelajaran Ipa Kelas V Sd. Analisis Aspek Literasi Sains Pada Buku Teks Pelajaran Ipa Kelas V Sd, 4(1), 56-66. Https://Doi.Org/10.23819/Mimbar-Sd.V4i1.5585

Nurlaila, M. (2019). Kemampuan Menceritakan Kembali Isi Cerita Pendek "Ibu" Karya Heriyanto. Jurnal Edukasi Cendikia, 3(2), 53-58. Https://Www.Jurnal-Umbuton.Ac.Id/Index.Php/Jec

Nuro, F. R. M., Suwandayani, B. I., \& Majid, I. N. (2020). Penerapan Literasi Sains Di Kelas Iv Sekolah Dasar. Jurnal Pemikiran Dan Pengembangan Sekolah Dasar (Jp2sd), 8(2), 179-187. Https://Doi.Org/10.22219/Jp2sd.V8i2.15189

Suyono, Titik, H., \& Wulandari, I. S. (2017). Implementasi Gerakan Literasi Sekolah Pada Pembelajaran Tematik Di Sekolah Dasar. Sekolah Dasar: Kajian Teori Dan Praktik Pendidikan, 26(2), 116-123. Http://Journal2.Um.Ac.Id/Index.Php/Sd/Article/View/3050

Yunianika, I. T., \& . S. (2019). Implementasi Gerakan Literasi Sekolah Di Sekolah Dasar Dharma Karya Universitas Terbuka. Jurnal Ilmiah Sekolah Dasar, 3(4), 507. Https://Doi.Org/10.23887/Jisd.V3i4.17331

Yuliati. Y. (2016). Literasi Sains Dalam Pembelajaran Ipa. Jurnal Cakrawala Pendas, 53(9), 1689-1699. 